\title{
On the cooling of a wire when stretched
}

\section{E. Dorn}

To cite this article: E. Dorn (1886) On the cooling of a wire when stretched, Philosophical Magazine Series 5, 21:128, 80-80, DOI: 10.1080/14786448608627814

To link to this article: http://dx.doi.org/10.1080/14786448608627814

册 Published online: 29 Apr 2009.

Submit your article to this journal

Џ Article views: 2

Q View related articles $₫$ 


\section{A NEW FORM OF ABSORPTION-CELL.}

BY ARTHUR E. BOSTWIOK.

The writer has devised and used the cell described below for the purpose of obtaining the absorption-spectra of liquids which bave but little selective absorption, and which would therefore have to be used ordinarily in large quantities.

The cell is a rectangular box about six inches long by three broad and three in height. The bottom and the two ends are of pine wood, covered with shellac, and the two sides are of ordinary looking-glass, cemented to the wood, so that the box is water-tight. The reflecting surface of the looking-glass is turned inward, and at each of two diagonally opposite corners the amalgam is scraped away so as to make a vertical slit about two millimetres in width. One of these is placed close to the spectroscope-slit, and through the other a parallel beam of light is admitted. It is evident that the box may be so placed that the beam will be internally reflected in it a number of times, depending upon the angle between the two, and will finally pass through the second slit into the spectroscope. The length of its path through the cell may therefore be varied indefinitely by turning the latter, and is iimited only by the decrease in intensity caused by general absorption-not only in the liquid, but also at each reflection.

A solution of bichromate of potash, so weak that a test-tube full of it was of a barely perceptible yellow colour and showed no absorption at all when beld before the spectroscope-slit, when placed in this cell, absorbed the whole upper end of the spectrum, the $\mathbf{F}$ line being scarcely visible. In this case sunlight was used, the beam being reflected six times, and having a path whose length inside the cell was about two feet. With mirrors of polished metal the result might be even better, since the absorption in the glass would be eliminated. In this case however the number of liquids which could be used in the cell would be somewhat limited. -Silliman's American Journal, December 1885.

ON THE COOLING OF A WIRE WHEN STRETCHED. BY E. DORN.

A steel wire about 0.7 millim. in diameter is clamped at the top, while to the lower end is fixed a scale-pan in which weights can be placed. Round two adjacent places of the principal wire a thin German silver and a steel wire are wound, the ends of which are connected with the galvanometer in such a way that a thermo element (steel-argentan) is formed. When weights are placed in the pan the galvanometer shows a cooling, and a warming when they are removed. With a Wiedemann's galvanometer, which was almost dead-beat, arranged for objective representation, with lamp, lens, and scale, I got a deflection of several centimetres. The places of contact of the heterogeneous metals must be protected from air-currents by means of felt.-Wiedemann's Annalen, vol. xxvi. p. 334. 